\title{
THE EFFECT OF FEEDING PROTEIN AND UREA ON THE RENAL CONCENTRATING PROCESS ${ }^{1}$
}

\author{
By FRANKLIN H. EPSTEIN, ${ }^{2}$ CHARLES R. KLEEMAN, STEWART PURSEL, ${ }^{3}$ \\ AND ACHIEL HENDRIKX \\ (From the Department of Internal Medicine, Yale University School of Medicine, \\ New Haven, Conn.)
}

(Submitted for publication December 7, 1956; accepted December 28, 1956)

The role of dietary protein in the treatment of renal disease remains a controversial one, in part because the influence of diets high or low in protein upon normal renal function is not completely understood. In the rat much evidence has accumulated that high-protein intakes lead to renal hypertrophy (1-3) and that low-protein diets may be associated with impairment of some renal functions (4). Pullman, Alving, Dern, and Landowne (5) have recently reviewed this subject and demonstrated that in normal men a high-protein diet slightly increases and a low-protein diet slightly depresses glomerular filtration rate, renal plasma flow and $\mathrm{T}_{\mathrm{m}} \mathrm{PAH}$.

The present experiments were undertaken to investigate the effects of alterations in dietary protein on the ability of normal kidneys to concentrate the urine. Maximum renal concentrating capacity was altered strikingly by changing the dietary intake of nitrogen, both as protein and (an unexpected finding) as preformed urea.

\section{METHODS}

Normal young men abstained from fluids for 12 hours prior to coming to the laboratory at $8 \mathrm{a} . \mathrm{m}$. on the day of the experiment. In order to assure a constant and maximal antidiuretic stimulus throughout all experiments, Pitressin 4 was infused at the rate of 200 milliunits in $50 \mathrm{cc}$. of normal saline per hour. Subjects remained in the supine position, standing only to void. Urine was collected at intervals until its osmolal concentration (freezing point) had reached a constant maximum. In some subjects mannitol was then infused, so that the maximum ability of renal tubules to reabsorb

${ }^{1}$ Supported by grants from the U. S. Public Health Service, the Wyndham County, New Haven (Conn.) and American Heart Associations and a contract (MD116) with the Office of the Surgeon General, Department of the Army.

2 Established Investigator of the American Heart Association.

3 James Hudson Brown Student Fellow, 1955.

4 Parke, Davis and Co., Lot No. R983M. water free of solute $\left(\mathrm{T}_{\mathrm{m}}{ }^{\mathrm{e}} \mathrm{H}_{2} \mathrm{O}\right)$ could be measured in 5 to 16 separate determinations within a range of urine flows from 10 to $35 \mathrm{cc}$. per min. Freezing points of serum and urine were determined using the Fiske osmometer. Clearances of inulin (6), creatinine (7), urea (8), sodium and potassium (9) were also determined. The " $t$ " test of "Student" was used in analyzing the data.

Each subject was studied after three days on a LowProtein diet, containing approximately 20 grams of protein per day, and a High-Protein diet, containing 150 to 200 grams of protein per day. The latter was achieved by the use of 100 to 200 grams per day of a high-protein, low-sodium supplement. 5 Both diets were approximately isocaloric; in some subjects the low-protein diet consisted chiefly of carbohydrate, in others fat predominated. Two subjects were studied on a Regular diet, containing about 90 grams of protein per day. Other variations in dietary regimen will be described under Results.

\section{RESUltS (Table I)}

Effect of low-vs. high-protein diets on renal concentrating ability, inulin clearance and urea clearance (Figure 1)

Maximum urinary solute concentration and maximum osmolal $U / P$ ratio were invariably higher after three days of a high-protein intake than after a diet low or normal with respect to protein. The increases in maximum urinary osmolality with ingestion of large amounts of protein varied from 87 to $332 \mathrm{mOsm}$. per $\mathrm{K}$. This occurred in association with an increased basal urinary flow containing from 1.2 to 5 times the quantity of solutes excreted on a low-protein diet. The maximum capacity of the kidneys to reabsorb water free of solute $\left(\mathrm{T}_{\mathrm{m}} \mathrm{H}_{2} \mathrm{O}\right)$ was likewise increased by 15 to 50 per cent in five subjects by feeding protein.

Inulin clearance was slightly higher in each of five subjects on a high-protein regimen than on a diet low in protein. At the high urine flows obtained during mannitol diuresis, the clearance of

${ }^{5}$ Melactin, supplied by E. R. Squibb and Co. 


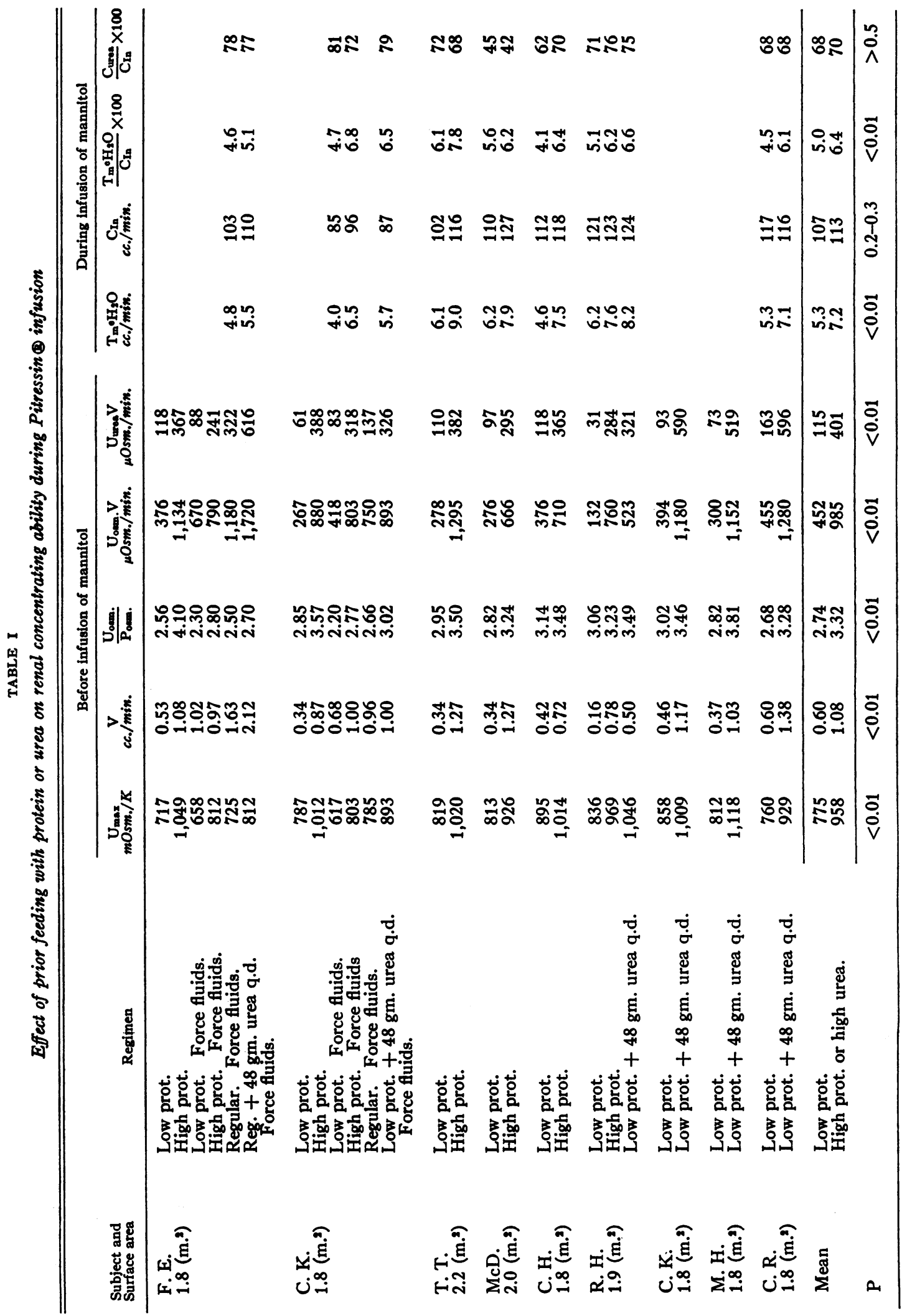




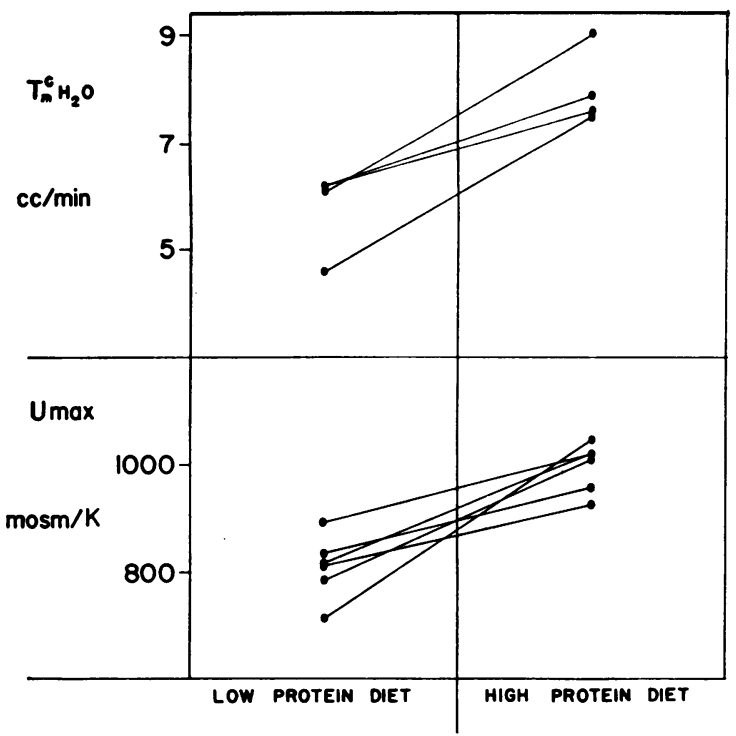

Fig. 1. Effect of Dietary Protein on Renal ConCentrating Ability

urea averaged 70 per cent of inulin clearance. Protein feeding did not change this ratio.

Failure of sodium chloride to improve renal concentrating ability (Figure 2)

In contrast to the effects of protein ingestion on renal concentrating ability, maximum urinary concentration, maximum $\mathrm{U} / \mathrm{P}$ ratio and $\mathrm{T}_{\mathrm{m}} \mathrm{cH}_{2} \mathrm{O}$ were unchanged or slightly diminished when a

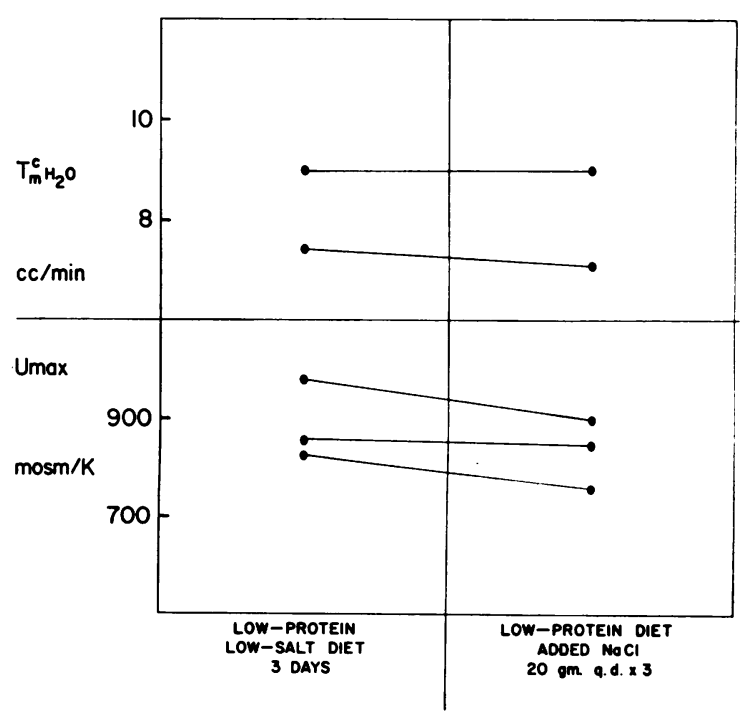

Fig. 2. Effect of NaCl on Renal Concentrating AbIlity

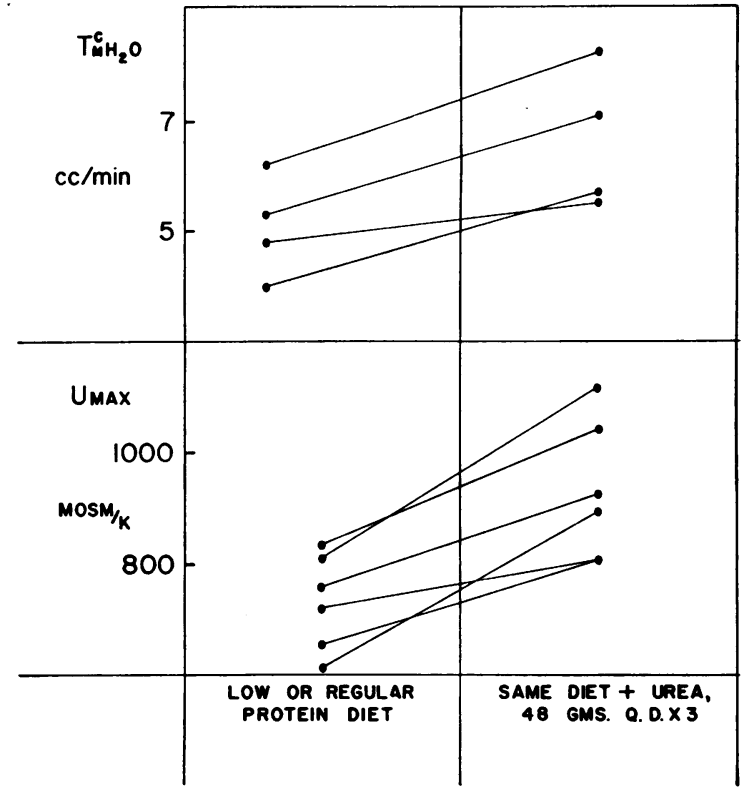

Fig. 3. Effect of Urea on Renal Concentrating AbILITy

low-protein diet was supplemented by 20 grams of sodium chloride per day (equivalent in osmolar terms to the urea from 100 grams of protein) for three days prior to the test. An increased excretory burden of solute supplied as electrolyte did not, therefore, produce the same increase in renal concentrating capacity as did solute derived from protein.

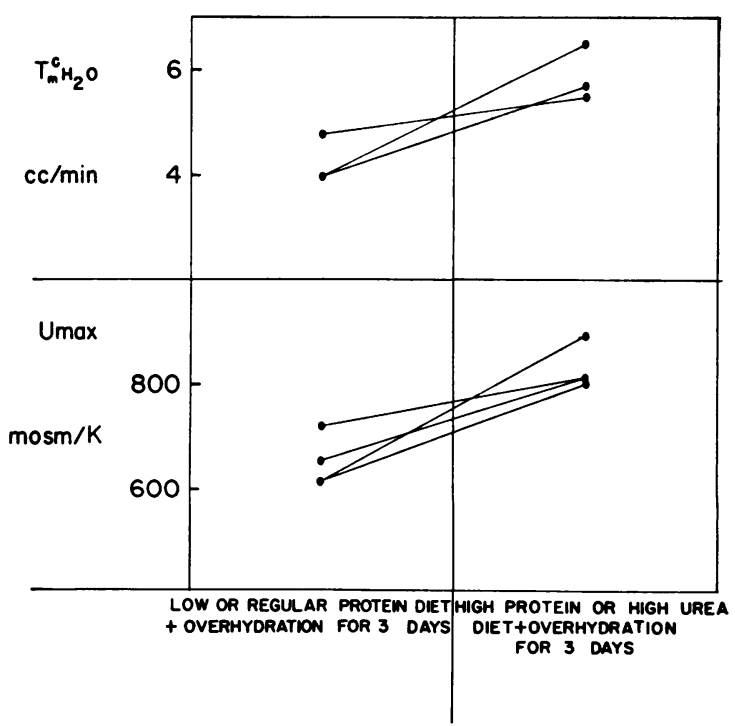

Fig. 4. Effect of Protein and Urea on Renal Concentrating Ability in Overhydrated Subjects 


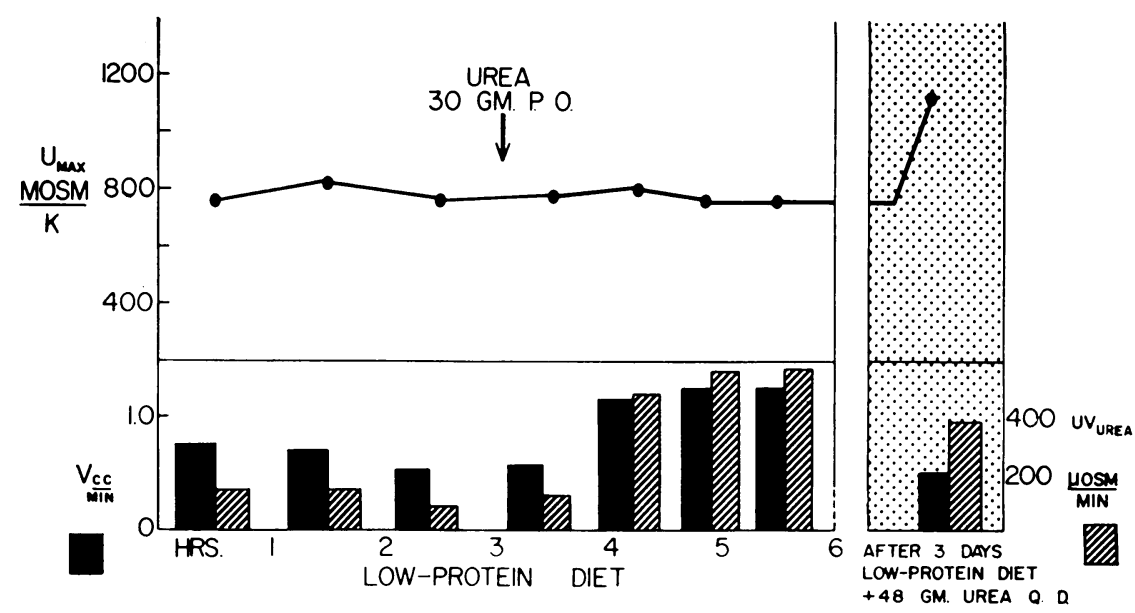

Fig. 5. Frfect of Acete is. Chronic Urea Ionding ox Maximext Urinary Concentration

Effect of adding urea to the dict (Figure 3)

When a low-protein diet was supplemented for three days, not by 140 grams of extra protein but by an equivalent amount of nitrogen in the form of 48 grams of urea daily, a marked increase occurred in maximum urinary concentration, maximum $\mathrm{U} / \mathrm{I}$ ' ratio and $\mathrm{T}_{\mathrm{m}}{ }^{\mathrm{c}} \mathrm{H}_{2} \mathrm{O}$. This effect, observed in six instances, was in all respects indistinguishable from that seen in sul)jects eating a diet high in protein.
Effects of protein and urea in owerhydrated subiects (Figure t)

It seemed possible that the effects of protein and urea might be secondary to some slight or inapparent dehydration consequent to solute diuresis and insufficiently compensated for by the subject's sense of thirst. Two subjects (F. E. and C. K.) were studied repeatedly on diets low and high in protein. with and without supplements of urea. taken during a period of three days during which

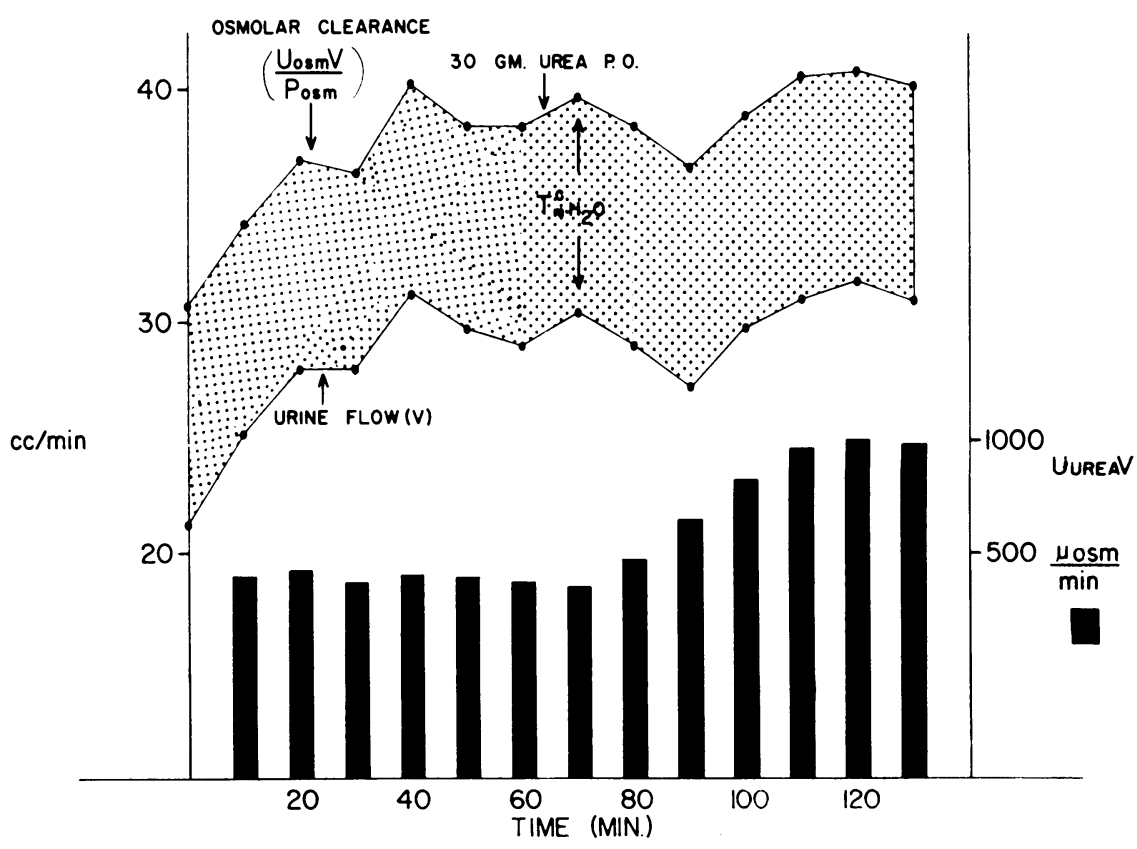

SUBJECT S.P LOW-PROTEIN DIET. INFUSION OF MANWITOL + PITRESS IN

Fig. 6. Fallure of Acute Ixgestion of Urea to Ixcrease T m 
5 to 6 liters of water were imbibed daily, an amount sufficient to keep the measured concentration of each specimen of urine voided during this time below $150 \mathrm{mOsm}$. per $\mathrm{K}$. With the possibility of dehydration thus eliminated, supplementary feedings of protein and urea consistently increased maximum urinary concentration and $\mathrm{T}_{\mathrm{m}} \mathrm{H}_{2} \mathrm{O}$.

Failure of acute loading with urea to increase $U_{\text {max }}$ or $\mathrm{T}_{m}{ }^{c} \mathrm{H}_{2} \mathrm{O}$ (Figures 5 and 6)

Four subjects who had eaten a diet low or normal in protein for the preceding three days ingested 30 grams of urea acutely while receiving an infusion of Pitressin ${ }^{\circledR}$. A typical experiment is shown in Figure 5. The osmolality of the urine was essentially unaltered although the excretion of urea quadrupled. On the other hand, maximum urinary concentration was considerably increased in every case after the same subject supplemented his diet with urea for three days. $\mathrm{T}_{\mathrm{m}} \mathrm{CH}_{2} \mathrm{O}$ was not changed by the acute ingestion of 30 grams of urea in two subjects in whom this was tested (Figure 6).

\section{DISCUSSION}

Data in the literature concerning the influence of dietary variations on renal concentrating ability are scanty and conflicting. Addis and Shevky (10) suggested that healthy persons deprived of water might excrete urine of subnormal specific gravity when their diets contained little salt and protein; however, the differences which they obtained were of questionable statistical significance and were not confirmed by Miller, Price, and Longley (11) or by Addis and Foster (12), who in addition pointed out the fallacy of using specific gravity as a measure of osmolar concentration. McCance (13) found that maximum urinary osmolarity after dehydration was not changed appreciably by omitting salt from the diet or by ingesting urea on the morning of the experiment. Hayman, Shumway, Dumke, and Miller (14) reported that two dogs when deprived of fluids excreted urine of lower specific gravity while on a cracker-meal diet than when eating a diet composed largely of meat.

The effect of protein in producing hypertrophy of the kidneys of rats is well known (1-3). When the diet of rats is supplemented by nitrogen in the form of urea, renal hypertrophy, less marked than with protein feeding, has been reported $(2,15,16)$ and denied $(1,3)$. Other urinary solutes, with the possible exception of phosphate, do not enhance renal growth (1). Protein feeding greatly increases renal blood flow and glomerular filtration rate in the dog (17) but in man (5) it produces only a slight, though statistically significant, rise in the clearances of inulin and $\mathrm{PAH}$ and in $\mathrm{T}_{\mathrm{m}} \mathrm{PAH}$.

The idea that urea might obligate less water in the urine than an equimolar quantity of salt, or that maximum concentrations of urea could be attained in a urine already maximally concentrated with respect to salt was suggested by earlier workers $(18,19)$, but Hervey, McCance, and Taylor $(20,21)$ concluded from acute studies in healthy persons during hydropenia that at every urine flow there was a limiting osmotic pressure which did not discriminate between osmols of urea and osmols of salt. ${ }^{6}$ The present experiments indicate that in order for urea to raise maximum urinary osmolarity it must be administered over several days. It is therefore unlikely that its effect can be explained solely or chiefly by an unusual ability of the renal tubules to concentrate urea per se to a greater extent than other solutes. If that were the case, prior feeding of protein or urea would not increase urinary osmolality measured during the determination of $\mathrm{T}_{\mathrm{m}} \mathrm{c}_{2} \mathrm{O}$, when mannitol and not urea is the chief osmotic constituent of the urine. Even if the assumption is made that urea obligates no water at all, only 20 to 50 per cent of the increases in $\mathrm{T}_{\mathrm{m}}{ }^{\mathrm{c}} \mathrm{H}_{2} \mathrm{O}$ observed in the present experiments after diets high in protein or urea could be accounted for by the presence of additional urea in the urine under mannitol diuresis.

The ability of renal tubules to secrete urea into the urine has been established for the kidney of the aglomerular fish (22), the frog $(23,24)$ and the kangaroo rat (25). It is conceivable that a

6 It should be pointed out, however, that there are no published data dealing intensively with the effects of urea vs. other solutes on the limiting osmotic pressure of the urine in man below a urine flow of about $3 \mathrm{cc}$. per min. Scattered observations suggest that during hydropenia a maximum urinary osmolal concentration may be maintained at somewhat higher levels of urine flow and solute excretion when urea is utilized as a loading solute than when sodium chloride is loaded (13). 
similar mechanism, stimulated by the necessity to excrete large amounts of urea, might operate in humans to add urea to tubular urine at or past the point where water is abstracted in the final concentrating process. Such a process should, however, be reflected in a rise in the urea/inulin clearance ratio. This did not occur in the present experiments in which $\mathrm{C}_{\text {urea }} / \mathrm{C}_{\text {inulin, }}$, measured during osmotic diuresis, was remarkably constant on both high and low-protein diets. Secretion of urea by renal tubules is therefore not a likely explanation for the augmentation of renal concentrating ability which was observed during mannitol diuresis in persons fed protein or urea. These data do not rule out the possibility that increased tubular secretion of urea might operate at low urine flows to increase maximum urinary osmolality, an effect which might be submerged in the flood of proximal tubular urine accompanying mannitol diuresis. It is interesting in this connection that Schmidt-Nielsen observed that mannitol appeared to block tubular excretion of urea in the kangaroo rat (25).

Although the kidneys can apparently be "trained" to concentrate more or less efficiently by several days of water deprivation or of forced drinking (26), the explanation of the influence of protein and urea on the concentrating process does not lie with any tendency they might have to produce dehydration. Dietary supplements of protein and urea improved renal concentrating ability in continuously overhydrated subjects as well as in persons permitted to drink at will.

It seems clear that physiological variations in dietary protein and urea excretion, as well as in the state of bodily hydration (26), produce wellmarked and separable adaptive responses on the part of the renal tubules which have an obvious utility in terms of the body's economy of water. Such effects upon renal concentrating ability cannot be neglected in future considerations of the effects of disease or therapy upon this important function of the kidneys.

\section{SUMMARY}

1. Changes in the dietary intake of nitrogen, either as protein or urea, over a period of three days, in normal subjects produced well-marked parallel changes in maximum urinary osmolal concentration and in $\mathrm{T}_{\mathrm{m}}{ }^{\mathrm{c}} \mathrm{H}_{2} \mathrm{O}$.
2. Feeding of protein or urea increased the renal response to Pitressin ${ }^{\circledR}$ in continuously overhydrated subjects as well as in persons permitted to drink at will.

3. Although $\mathrm{U}_{\max }$ and $\mathrm{T}_{\mathrm{m}} \mathrm{c}_{2} \mathrm{O}$ were increased by chronic administration of urea, they were not increased by acute urea loading.

4. The data suggest that both protein and urea, when administered chronically, promote an adaptive response by the renal tubules by which water is conserved more efficiently and renal concentrating ability is augmented.

\section{REFERENCES}

1. Osborne, T. B., Mendel, L. B., Park, E. A., and Winternitz, M. C., Physiological effects of diets unusually rich in protein or inorganic salts. $\mathrm{J}$. Biol. Chem., 1927, 71, 317.

2. Wilson, H. E. C., An investigation of the cause of renal hypertrophy in rats fed on a high protein diet. Biochem. J., 1933, 27, 1348.

3. MacKay, E. M., Factors which determine renal weight. XIV. The relative influences of amino, urea and protein nitrogen in the diet. J. Nutrition, 1933, 6, 157.

4. Dicker, S. E., Heller, H., and Hewer, T. F., Renal effects of protein-deficient vegetable diets: a functional and histological study. Brit. J. Exper. Path., 1946, 27, 158.

5. Pullman, T. N., Alving, A. S., Dern, R. J., and Landowne, M., The influence of dietary protein intake on specific renal functions in normal man. J. Lab. \& Clin. Med., 1954, 44, 320.

6. Roe, J. H., Epstein, J. H., and Goldstein, N. P., A photometric method for the determination of inulin in plasma and urine. J. Biol. Chem., 1949, $178,839$.

7. Hare, R. S., Endogenous creatinine in serum and urine. Proc. Soc. Exper. Biol. \& Med., 1950, 74, 148.

8. Conway, E. J., Microdiffusion Analysis and Volumetric Error. 3rd rev. ed., London, C. Lockwood, 1950.

9. Hald, P. M., The flame photometer for the measurement of sodium and potassium in biological materials. J. Biol. Chem., 1947, 167, 499.

10. Addis, T., and Shevky, M. C., A test of the capacity of the kidney to produce a urine of high specific gravity. Arch. Int. Med., 1922, 30, 559.

11. Miller, M., Price, J. W., and Longley, L. P., Effect of varying intake of protein and salts on the composition and specific gravity of urine. J. Clin. Invest., 1941, 20, 31 .

12. Addis, T., and Foster, M. G., The specific gravity of the urine. Arch. Int. Med., 1922, 30, 555.

13. McCance, R. A., The excretion of urea, salts and water during periods of hydropaenia in man. J. Physiol., 1945, 104, 196. 
14. Hayman, J. M., Jr., Shumway, N. P., Dumke, P., and Miller, M., Experimental hyposthenuria. J. Clin. Invest., 1939, 18, 195.

15. MacKay, L. L., MacKay, E., and Addis, T., Factors which determine renal weight. XII. The nitrogen intake as varied by the addition of urea to the diet. J. Nutrition, 1931, 4, 379.

16. Osborne, T. B., Mendel, L. B., Park, E. A., and Winternitz, M. C., Variations in the kidney related to dietary factors. Am. J. Physiol., 1925, 72, 222.

17. Pitts, R. F., The effects of infusing glycin and of varying the dietary protein intake on renal hemodynamics in the dog. Am. J. Physiol., 1944, 142, 355.

18. Ambard, L., and Papin, E., Etude sur les concentrations urinaires. Arch. Internat. de physiol., 1909, 8, 437.

19. Davies, H. W., Haldane, J. B. S., and Peskett, G. L., The excretion of chlorids and bicarbonates by the human kidney. J. Physiol., 1922, 56, 269.
20. Hervey, G. R., McCance, R. A., and Taylor, R. G. O., Further observations on the causes of a diuresis during hydropenia. J. Physiol., 1946, 104, 43P.

21. Hervey, G. R., McCance, R. A., and Taylor, R. G. O., Forced diuresis during hydropenia. Nature, 1946, 157, 338.

22. Marshall, E. K., Jr., and Grafflin, A. L., The function of proximal convoluted segment of the renal tubule. J. Cell. \& Comp. Physiol., 1932, 1, 161.

23. Marshall, E. K., Jr., The secretion of urea in the frog. J. Cell. \& Comp. Physiol., 1933, 2, 349.

24. Walker, A. M., and Hudson, C. L., The rôle of the tubule in the excretion of urea by the amphibian kidney. With an improved technique for the ultramicro determination of urea nitrogen. Am. J. Physiol., 1937, 118, 153.

25. Schmidt-Nielsen, B., Renal tubular excretion of urea in kangaroo rats. Am. J. Physiol., 1952, 170, 45.

26. Epstein, F. H., Kleeman, C. R., and Hendrikx, A., The influence of bodily hydration on the renal concentrating process. J. Clin. Invest., 1957, 36, 629. 